\title{
Materials Review
}

Architecture in France. Text in English and French by Yvone Lenard. 80 color slides by Wayne Rowe. New York: Harper and Row, 1973. Pp. 51, \$58.00.

Professor Lenard has assembled an illustrated course on the major monuments of French architecture from Carnac to ultramodern buildings along the Riviera. The colored slides are of good, although not of uniformly excellent quality, and the examples are generally well-chosen. A few reservations however: Why, even in a survey, totally ignore the great Burgundian romanesque works, Chenonceaux (preferring to it the Chateau d'Anet!), the Petit Trianon, the Hameau, and the works of Le Corbusier? Equally disturbing is the fact that there are no acceptable romanesque and gothic interiors to clarify different vaulting systems. A floor plan of a cathedral would also have been much appreciated.

At times, one feels that the texts (really notes) in French and English were too hastily put together: one footnote in the French text is written in English; a "vous" and a "des" are spelled "voux" and "dex." Worse, the explanations are often too brief. "Byzantine" and "oriental" influences on romanesque churches are pointed out, but the importance of the influences are never developed. Slides of the stained glass windows at Chartres and the accompanying notes are among the most detailed and the most interesting. Yet no indication of methods and problems of creating the glass or of techniques for assembling it are discussed. Five slides and commentaries are devoted to Versailles: One wonders why Le Vau, Mansart and Le Notre are nowhere mentioned.

This program will not fascinate the student the way Versailles and its Meaning (French Civilization as Reflected in the Arts Series: Cultural History Research) will. It will not sweep the Francophile off his feet with sound, color, and beauty as will Le Siecle des Lumieres (Warren Schloat Productions). On the other hand, it does not have the disadvantages of such programs either: It will not confuse the student; it will on the contrary clarify, elucidate, and ask the student precise factual questions and even give him the answers to these questions at the end of the program in written form.

\section{William Wrage \\ Modem Languages Department \\ Ohio University}

